\title{
Bovine-Origin Human Therapy; Need More Attention
}

\author{
AbdulRahman A. Saied ${ }^{1 *}$ and Asmaa A. Metwally ${ }^{2}$ \\ ${ }^{1}$ Aswan Office, Touristic Activities and Interior Offices Sector, \\ Ministry of Tourism, Aswan 81511, Egypt \\ ${ }^{2}$ Department of Surgery, Anesthesiology and Radiology, Faculty of Veterinary Medicine, \\ Aswan University, Aswan 81511, Egypt \\ *Corresponding author
}

\section{A B S T R A C T}

\section{Keywords}

Bovine, Viruses, Human, Therapy, Vaccines

Article Info

Accepted:

24 August 2019

Available Online:

10 September 2019
The nature of bovines` life enable them to form developed immune responses due to their exposure to many pathogens, besides their immune organs`characteristics. Bovine are herbivorous animals which make them a rich and safe source for human's therapies. The potential role of bovine in providing humans with antibodies in serum and milk in particularly the specific antibodies against human viruses or even relevant bovine viruses cannot be denied. Here, we shortly review the roles of bovine in human infections as a model for producing antibodies specific for human viruses and bacteria, designing vaccines as well the role of some bovine viruses in stimulating the human immunity memory against human viruses e.g. Rota vaccines.

\section{Introduction}

"And there is no creature on [or within] the earth or a bird that flies with its wings except [that they are] communities like you." (Cattle38), the Noble Quran. Although there are differences between human and bovines, the same approximate gestation period of 280 days between bovine and human suggest the near immune response between them ${ }^{1}$. Colostrum or serum-rich in antibodies from bovine can be used against human diseases caused by viruses and also bacteria.

\section{Antibodies-rich Colostrum}

It's not new the natural health benefits of bovine colostrum especially for human children $^{2,3}$ who consume it for nutrition, immunity and growth ${ }^{4}$. Cow colostrum contains $\operatorname{IgG}$ levels higher than that of woman colostrum as bovine IgG does not cross the placenta in addition to lactoferrin, lactoperoxidase, lysozyme and other immune factors which have antiviral activities ${ }^{3,5}$. As a potential means of controlling human viral disease outbreaks ${ }^{6}$, bovine colostral and milk $\mathrm{IgG}$ were developed and applied as a passive 
immunity to human disease $\mathrm{d}^{7-12}$. Bovine colostrum may be beneficial in people infected with HIV $^{13}$, where $\mathrm{IgG}$ derived from colostrum enhances immune response to HIV. Antibodies from some leukemic cattle can inhibit HIV-1 reverse transcriptase activity in vitro $^{14}$. Use of polyclonal bovine antibodies as a therapy treat human pathogens ${ }^{12}$ is due to their potential for increased potency in the formation of immune complexes and neutralization of pathogens epitopes ${ }^{15}$ consequently preventing or control of human viral infections ${ }^{7-12,16}$. Against Rota virus, milk immunoglobulin concentrate could be used to induce passive immunity to infantile rotavirus gastroenteritis with thanks to the technology of the milk immunoglobulin concentrate ${ }^{17}$. Bovine lactoferrin plays an important role in the prevention of colon cancer ${ }^{18}$ which is the major cause of cancer death in developed and developing countries ${ }^{19}$.

Study carried out by Fang $\mathrm{He}$ et $a l^{20}$, suggested that the oral administration of bovine colostrum may possess some modulatory effect on human humoral immune response against enteropathogenic Salmonella typhi vaccine ${ }^{20}$, as well supplementation of infants with formula with Bovine MFGM induced immunomodulatory effects against pneumococcus vaccine ${ }^{21}$. Also, bovine antibodies could prophylactically reduce the carcinogenic bacteria transmission from mother to child and other pathogens (Shigella flexneri, Escherichia coli, Clostridium difficile, Cryptosporidium parvum and Helicobacter pylori) $)^{22,23}$ in human beings by passive immunity ${ }^{23}$ motivating the hypothesis of use of immune milk products as promising health-promoting functional foods, or nutraceuticals ${ }^{22}$.

\section{Bovine vaccination}

Bovine vaccination with Streptococcus mutans, the main aetiological agent in dental caries in humans, whole bacteria or purified components result in antibodies against $S$. mutans. Oral administration of these antibodies from immunized cows have been used successfully as prophylaxis against dental caries in both an animal experimental model and healthy volunteers.

Bovine vaccination with a specific human virus results in production of antigen-specific antibodies in sera and colostrum (Hyperimmune milk) of bovine ${ }^{13}$.Bovine yields remarkably high BrNAbs titers rather than other animal species after vaccination. Indeed, bovine antibodies from vaccinated cows could ultimately benefit for individuals infected with HIV through their extraordinary characteristics.

\section{Transchromosomic (Tc) bovines}

A creative study was carried out by Luke et al. ${ }^{26}$ using transchromosomic (Tc) bovines to produce human anti-MERS-CoV antibodies. This study demonstrated an efficacy in vitro and in a mouse model of MERS-CoV infection showing how large quantities of human MERS-CoV-neutralizing antibodies can be rapidly produced in Tc bovines, providing a possible strategy for the development of passive immunotherapy against coronaviruses or other new and emerging infectious diseases ${ }^{26}$. Fully human polyclonal antibodies, produced in $\mathrm{TcB}$, can be elicited against many viruses ${ }^{26-32}$ (Ebola Zaire Virus) and some of them have already been shown to be safe and effective in human clinical trials $^{30,33}$.

Bovine could be used in the biological production of human polyclonal antibodies where transgenic calves and transgenic platforms were created to produce polyclonal antibodies derived from animals and human sequences $^{34,35}$. Coping with the problem of that most polyclonal antibodies will target non-neutralizing epitopes ${ }^{13}$, through producing monoclonal BrNAbs targeting 
preserved epitopes among different subtypes of viruses with humanization of bovine monoclonal antibody ${ }^{36}$ reducing antiantibody responses ${ }^{37}$.
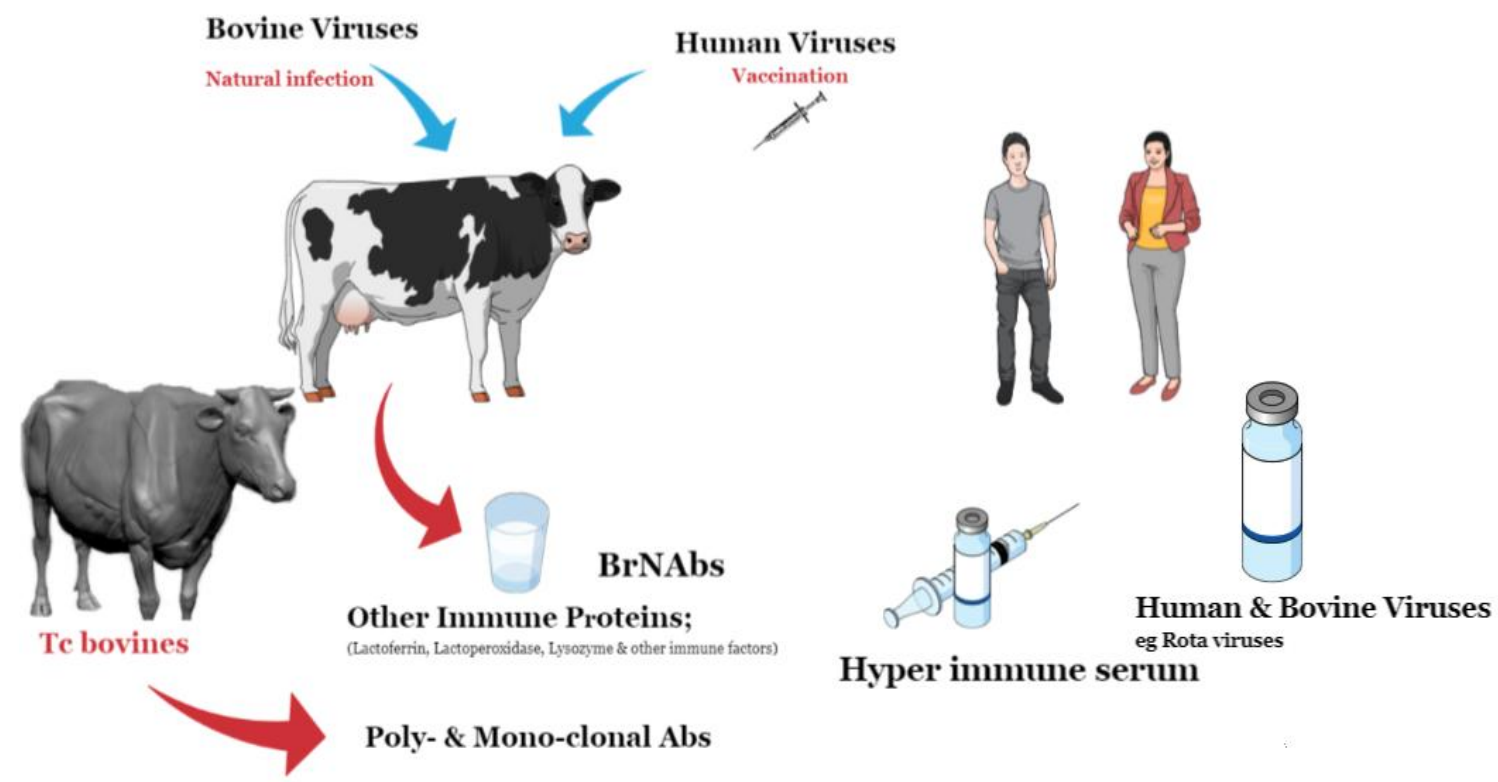

Hyper immume serum

Figure.1. Schematic diagram summarized the possible ways for getting bovine antibodies which play a pivotal role in human immunity and health. Bovine antibodies produced along the entire cow life against many pathogens exposed for, whatever bovine or human pathogens, natural infections or organized vaccinations. Tc bovines used as animal model system for producing antibodies against the emerging human viruses, the field which attracting researchers for more discoveries.

Based on Bovine - human rotaviruses reassortment, as a result of anthropozoonosis 38 , and human rotavirus attenuation in bovines $(\text { HRR })^{39}$, RotaShield and RotaTeq vaccines were developed $^{39}$ and both vaccines have been licensed in many countries.

In conclusion, the present review provides important insights into how to get human therapies from bovine with the need for presence of more advanced and sensitive technologies for achieving that. How bovine`s immunity respond to viruses infect humans and bovines help us more, in the light of the immunological studies, in preventing of humans against viral infections through vaccination and passive immunization.

\section{Abbreviation}

BrNAbs; broad neutralizing antibodies

HIV Env; Human immunodeficiency virus envelop
CD4bs; T-helper cell binding site

HCDR3; the heavy chain complementaritydetermining region 3

HRR; host-range restriction. MERS-CoV; Middle East Respiratory SyndromeCoronavirus.

Bovine MFGM; Bovine milk fat globule membranes

\section{Ethical statement}

No ethical approval was required for this study.

\section{Conflict of interests}

The author declares no financial or commercial conflict of interest.

\section{Author's contributions}

AAS prepared and reviewed the original draft 
of the manuscript. AAM discussed the manuscript idea and help in manuscript revision. Both authors read and approved the final manuscript.

\section{Acknowledgement}

AbdulRahman A. Saied would like to thank Aswan office, Ministry of Tourism for their encouragement and support.

\section{References}

1. Schultz RD, Dunne H, Heist C. Ontogeny of the bovine immune response. Infection and immunity. 1973;7(6):981-991.

2. Elfstrand L, Lindmark-Månsson $\mathrm{H}$, Paulsson $\mathrm{M}$, Nyberg L, Åkesson B. Immunoglobulins, growth factors and growth hormone in bovine colostrum and the effects of processing. International Dairy Journal. 2002;12(11):879-887.

3. Van Hooijdonk AC, Kussendrager K, Steijns J. In vivo antimicrobial and antiviral activity of components in bovine milk and colostrum involved in non-specific defence. British Journal of Nutrition. 2000;84(S1):127-134.

4. Hurley WL, Theil PK. Perspectives on immunoglobulins in colostrum and milk. Nutrients. 2011;3(4):442-474.

5. Ellison Rr, Giehl TJ. Killing of gram-negative bacteria by lactoferrin and lysozyme. The Journal of clinical investigation. 1991;88(4):1080-1091.

6. Alisky J. Bovine and human-derived passive immunization could help slow a future avian influenza pandemic. Medical hypotheses. 2009;72(1):74-75.

7. Struff W, Sprotte G. Bovine colostrum as a biologic in clinical medicine: A review-Part II. International journal of clinical pharmacology and therapeutics. 2008;46(5):211-225.

8. Struff W, Sprotte G. Bovine colostrum as a biologic in clinical medicine: review. Int $\mathrm{J}$ Clin Pharmacol Therapeut. 2007;45:193-202.

9. Zinkernagel RM. Maternal antibodies, childhood infections, and autoimmune diseases. New England Journal of Medicine. 2001;345(18):1331-1335.

10. Korhonen H, Marnila P, Gill H. Bovine milk antibodies for health. British Journal of Nutrition. 2000;84(S1):135-146.
11. Zeitlin L, Cone RA, Moench TR, Whaley KJ. Preventing infectious disease with passive immunization. Microbes and infection. 2000;2(6):701-708.

12. Weiner C, Pan Q, Hurtig M, Boren T, Bostwick E, Hammarström L. Passive immunity against human pathogens using bovine antibodies. Clinical and experimental immunology. 1999;116(2):193.

13. Heydarchi B, Quiroz N, Purcell D. Broad neutralizing antibodies to HIV env and other complex viral antigens from vaccinated cows. Journal of Vaccines \& Vaccination. 2016;7:347.

14. Gillet N, Florins A, Boxus M, et al. Mechanisms of leukemogenesis induced by bovine leukemia virus: prospects for novel anti-retroviral therapies in human. Retrovirology. 2007;4(1):18.

15. Lonberg N. Human antibodies from transgenic animals. Nature biotechnology. 2005;23(9):1117.

16. Wirt DP, Adkins LT, Palkowetz KH, Schmalstieg FC, Goldman AS. Activated and memory T lymphocytes in human milk. Cytometry: The Journal of the International Society for Analytical Cytology. 1992;13(3):282-290.

17. Brüssow H, Hilpert $H$, Walther I, Sidoti J, Mietens C, Bachmann PJJocm. Bovine milk immunoglobulins for passive immunity to infantile rotavirus gastroenteritis. 1987;25(6):982986.

18. Tsuda H, Kozu T, Iinuma G, et al. Cancer prevention by bovine lactoferrin: from animal studies to human trial. Biometals. 2010;23(3):399-409.

19. Rehman MU, Buttar QM, Khawaja M, Khawaja M. An impending cancer crisis in developing countries: are we ready for the challenge. Asian Pac J Cancer Prev. 2009;10(4):719-720.

20. He F, Tuomola E, Arvilommi H, Salminen SJFI, Microbiology M. Modulation of human humoral immune response through orally administered bovine colostrum. 2001;31(2):93-96.

21. Timby N, Hernell O, Vaarala O, et al. Infections in infants fed formula supplemented with bovine milk fat globule membranes. 2015;60(3):384-389.

22. Korhonen H, Marnila P, Gill HJBJoN. Bovine milk antibodies for health. 2000;84(S1):135-146.

23. Weiner C, Pan Q, Hurtig M, et al. Passive immunity against human pathogens using bovine antibodies. 1999;116(2):193.

24. Michalek S, Gregory R, Harmon C, et al. Protection of gnotobiotic rats against dental caries by passive immunization with bovine milk 
antibodies to Streptococcus mutans. 1987;55(10):2341-2347.

25. Filler S, Gregory R, Michalek S, Katz J, McGhee JJAoob. Effect of immune bovine milk on Streptococcus mutans in human dental plaque. 1991;36(1):41-47.

26. Luke $\mathrm{T}, \mathrm{Wu} \mathrm{H}$, Zhao J, et al. Human polyclonal immunoglobulin $\mathrm{G}$ from transchromosomic bovines inhibits MERS-CoV in vivo. Science translational medicine. 2016;8(326):326ra321$326 r a 321$.

27. Stein DR, Golden JW, Griffin BD, et al. Human polyclonal antibodies produced in transchromosomal cattle prevent lethal Zika virus infection and testicular atrophy in mice. Antiviral research. 2017;146:164-173.

28. Hooper JW, Brocato RL, Kwilas SA, et al. DNA vaccine-derived human IgG produced in transchromosomal bovines protect in lethal models of hantavirus pulmonary syndrome. Science translational medicine. 2014;6(264):264ra162-264ra162.

29. Bounds CE, Kwilas SA, Kuehne AI, et al. Human polyclonal antibodies produced through DNA vaccination of transchromosomal cattle provide mice with post-exposure protection against lethal Zaire and Sudan ebolaviruses. PloS one. 2015;10(9):e0137786.

30. Silver JN, Ashbaugh CD, Miles JJ, et al. Deployment of transchromosomal bovine for personalized antimicrobial therapy. Clinical Infectious Diseases. 2017;66(7):1116-1119.

31. Siddharthan V, Miao J, Van Wettere AJ, et al. Human Polyclonal Antibodies Produced from Transchromosomal Bovine Provides Prophylactic and Therapeutic Protections Against Zika Virus Infection in STAT2 KO Syrian Hamsters. Viruses. 2019;11(2):92.
32. Gardner CL, Sun C, Luke T, et al. Antibody preparations from human transchromosomic cows exhibit prophylactic and therapeutic efficacy against venezuelan equine encephalitis virus. Journal of virology. 2017;91(14):e00226-00217.

33. Beigel JH, Voell J, Kumar P, et al. Safety and tolerability of a novel, polyclonal human antiMERS coronavirus antibody produced from transchromosomic cattle: a phase 1 randomised, double-blind, single-dose-escalation study. The Lancet Infectious Diseases. 2018;18(4):410-418.

34. Kuroiwa Y, Kasinathan P, Choi YJ, et al. Cloned transchromosomic calves producing human immunoglobulin. Nature biotechnology. 2002;20(9):889.

35. Kuroiwa Y, Kasinathan P, Matsushita H, et al. Sequential targeting of the genes encoding immunoglobulin- $\mu$ and prion protein in cattle. Nature genetics. 2004;36(7):775.

36. Riechmann L, Clark M, Waldmann H, Winter G. Reshaping human antibodies for therapy. Nature. Mar 24 1988;332(6162):323-327.

37. Queen C, Schneider WP, Selick HE, et al. A humanized antibody that binds to the interleukin 2 receptor. Proceedings of the National Academy of Sciences of the United States of America. 1989;86(24):10029-10033.

38. Gentsch JR, Laird AR, Bielfelt B, et al. Serotype diversity and reassortment between human and animal rotavirus strains: implications for rotavirus vaccine 2005;192(Supplement_1):S146-S159.

39. Angel J, Franco MA, Greenberg HBJNrm. Rotavirus vaccines: recent developments and future considerations. 2007;5(7):529.

\section{How to cite this article:}

AbdulRahman A. Saied and Asmaa A. Metwally. 2019. Bovine-Origin Human Therapy; Need More Attention. Int.J.Curr.Microbiol.App.Sci. 8(09): 2766-2770.

doi: https://doi.org/10.20546/ijcmas.2019.809.318 